\title{
Role of Employers in Empowering Lecturers in Tahfiz Institutions of Malaysia
}

\author{
Azmil Hashim (Corresponding Author) \\ Faculty of Human Science, Universiti Pendidikan Sultan Idris (UPSI), Tanjong Malim, \\ 35900 Perak, Malaysia \\ Tel: +60193375119 E-mail: azmil@fsk.upsi.edu.my \\ Mohamad Marzuqi Abdul Rahim \\ Faculty of Human Science, Universiti Pendidikan Sultan Idris (UPSI), Tanjong Malim, \\ 35900 Perak, Malaysia \\ Tel: +6019-6607574 E-mail: marzuqi@fsk.upsi.edu.my \\ Wahyu Hidayat Abdullah \\ Faculty of Human Science, Universiti Pendidikan Sultan Idris (UPSI), Tanjong Malim, \\ 35900 Perak, Malaysia \\ Tel: +60195723122 E-mail: wahyu@fsk.upsi.edu.my
}

\begin{abstract}
This study aimed to reveal the lecturers and employers perceptions on the role of employers in empowering lecturers through the provision of spiritual faith incentives, material incentives (scheme of service) and maknawi (abstract) incentives (working environment). This study involves 177 lecturers as samples and six employers of Darul Quran and MTQN. In order to achieve the objectives, a set of questionnaire which contains 51 items is used as instrument to measure the perception of lecturers on the role of employers. Meanwhile semi-structured interview that contains three questions is used to obtain opinions on the role played by employers. The questionnaire were analyzed descriptively and the overall results shows employers role in empowering lecturers are at a high level with mean value at 3.58. The interview result shows that there is a difference of views between lecturers and employers on material incentives (scheme of service). This study implied that scheme of service incentive should be upgrade to make it more equitable and inclusive, while maintaining spiritual faith incentives and maknawi incentives (working environment) are to continuously empowering lecturers.
\end{abstract}

Keywords: Darul Quran; Tahfiz Institutions; Spiritual Faith Incentives; Maknawi Incentives

\section{Introduction}

Al-Quran is the source of strength of Muslim ummah which has been revealed by Allah, Glory to Him the Exalted to the Prophet (pbuh) (peace be upon him) as manhajul hayat to the universe as word of Allah (Al-Quran, 17:9) Meaning: "Indeed, this Qur'an guides to that which is most suitable and gives good tidings to the believers who do righteous deeds that they will have a great reward". By using al-Quran, the Prophet (pbuh) has managed to build a viable Muslim community through Quranic education in a practical way. His effort has become a role model and it has been continued by asSalaf as-Saleh (pious Predecessors) who put the Quran as top priority in early education to Muslim children as the words of the Prophet narrated by Uthman ibn Affan r.a. which means: The best amongst you is the one who learns the Quran and teaches it. This process continues until today whereby Muslims seek to preserve the Quran by memorizing it in their chests or through writing in the mushaf as a first step to understand and practice the Quran with more consistent. Thus Malaysian government 
since the beginning of independence, in 1960 has taken steps in building a tahfiz al-Quran educational centre. The idea was sparked by Tunku Abdul Rahman Putra Al-Haj, the first Prime Minister of Malaysia at the opening of the National Mosque on the advice of Sheikh Ul Azhar Sheikh Mahmoud Shaltut. This centre was originally known as the Masjid Negara Tahfiz Quran class. It then developed into an institute, known as Maahad Tahfiz al-Quran (MTQ). It progress further until it is placed in a separate complex called Darul Quran (DQ).

Since the inception, Darul Quran has offer Diploma in Tahfiz al-Quran, which is recognized by the Public Services Department. Darul Quran is not alone in promoting Tahfiz alQuran education. It has been cooperating with other state-religious schools in academic field. Diploma in Tahfiz al-Quran Program was introduced, whereby Darul Quran curriculum is used and periodical assessment system is applied to ensure compliance with the requirements of academic and examination of Darul Quran. Meanwhile, Darul Quran progresses rapidly and it offers certification programs in tahfiz in collaboration with International Islamic University of Malaysia, Higher Certificate Program in Taranum, Malaysian Certificate Program in Tahfiz, and increases specialization for diploma program other than qiraat, i.e. da'wah specialization, syariah, hadith, commercial (muamalat) and halal certificate. Moreover, Darul Quran also began offering degree programs in al-Quran and al-Sunnah in collaboration with Universiti Sains Islam Malaysia since 2008.In view of rapid development of Darul Quran (DQ) and State Maahad Tahfiz al-Qur'an schools (MTQN) as centres of Quran higher learning in Malaysia, empowerment of lecturers who are backbones to the rise and fall of Tahfiz Quran learning must be looked into appropriately. This is emphasized by Al-Rabiie (2008) as lecturers are the catalyst for any educational institution glory.

\section{Research Background}

Even though DQ and MTQN have over 50 years of operation, statistically shown that the percentages of visiting and part-time lecturers are $65 \%$, as a matter of fact some MTQN has a much higher percentage (Mohamad Marzuqi, 2008). As in teaching field, the findings of Azmil et al. (2013) on valuation inputs of allocation time on tahfiz Teaching \& Learning (T\&L) showed dissatisfaction among lecturers on allocation of time and period given in DQ and MTQN. This is supported by Fatahurrahman (2006) who found that time for T\&L of memorization of the Quran with lecturers is insufficient and extremely limited because more time is focused on tasmi' memorization. According to Zawawi (2008), time spent in T\&L should be appropriate with the factors such as the ability of the learners, and material or syllabus used. In addition, in teaching and learning tahfiz, teaching aids (ABM) is not provided adequately by the institute (Azmil, 2010). For example, in terms of writing and research the data from Darul Quran publishing unit (2013) showed that overall, only $42 \%$ of articles are contributed by lecturers of DQ and MTQN while the rest are from the higher learning institutions. The problem faced by these lecturers should get serious attention by employer; with a strategy which should be drawn to encourage improvement in their work quality through fair and effective incentives.

Islamic religion highly emphasizes the provision of incentives or encouragement to worker as the word of Allah (Al-Quran, 9:105) Meaning: And say, "Do [as you will], for Allah will see your deeds, and [so, will] His Messenger and the believers. And you will be returned to the Knower of the unseen and the witnessed, and He will inform you of what you used to do". According to Al-Ibrahim (1988), work incentives model in Islam is divided into three; spiritual faith incentives, maknawi incentives (working environment) and material incentives (scheme of service) where spiritual faith incentives is the core to all incentives. Spiritual 
faith incentives are the foundation or principle to achieve Allah's pleasure in practical or work (Badar, 1985; Fadhlullah, 1996). It is followed by maknawi and maddiy incentives which are complementary to each other as shown by the work incentives model as follows

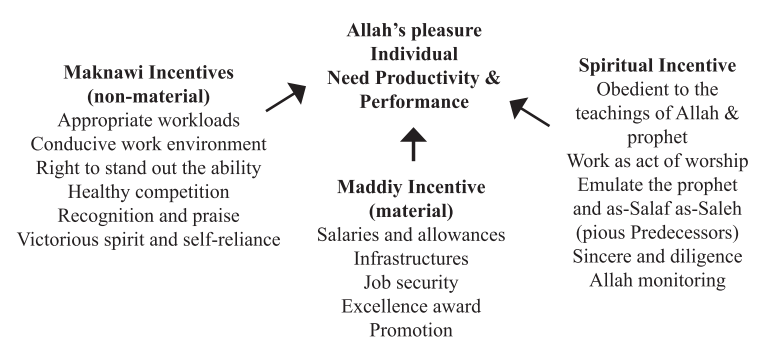

Source: (Al-Ibrahim, Islamic Work Incentives Model)

It is clearly shown that the lecturers are important workforce in developing any education institution. They need support and encouragement in various forms of incentives in order to achieve the pleasure of Allah, to meet the demands of self actualization and improvement in work quality. This fact has been supported by Al-Khatieb (2009) which asserts that consideration be given to variety of incentives will encourage employees to improve quality of work and provide them with job satisfaction. On the contrary, a survey by Marzuqi (2013) which was conducted on 11 lecturers found that $72 \%$ of them stated that they lack in incentives to improve their work performance. This predicament has prompted the authors to carry out a study in order to answer the following question.

\section{Research Question}

What is the level of empowerment of lecturers by employers of Darul Quran and MTQN?

\section{Methodology}

In order to achieve the objectives of this study, the author has conducted a descriptive study which applies qualitative and quantitative research methods (mixed approached). Modified questionnaires from previous studies have been used for data collection among the lecturers. Meanwhile, semi-structured interviews were conducted to obtain the employers view on the level of lecturer's empowerment by Darul Quran and MTQN employers.

\section{Results \& Discussion}

The findings are in the form of descriptive with percentage value, mean and standard deviation are determined for questionnaire items which measures the perception of lecturers on the role of employers in the empowerment of lecturers at the DQ and MTQN. Meanwhile the qualitative data is from interviews with some employers and are detailed for each construct.

\section{The Role of Employer in Empowering Lecturers}

Overall, the findings show that the role of employers in empowering lecturers in Maahad Tahfiz al-Quran is at moderate level with mean value at 3.58. Table 1 shows that Spiritual Faith Incentives gets the highest mean value at 4.19, followed by working environment incentives which is also at a high level with mean value at 3.83, while material incentives (scheme of service) is moderate with a mean value at 3.05.

\begin{tabular}{|c|c|c|c|c|}
\hline No. & Constructs & Mean & S.D & Level \\
\hline 1 & Spiritual faith incentives & 4.19 & 0.93 & High \\
\hline 2 & $\begin{array}{c}\text { Working environment } \\
\text { incentive }\end{array}$ & 3.83 & 0.90 & High \\
\hline 3 & Scheme of service incentive & 3.05 & 1.20 & Moderate \\
\hline & Total of Management Role & 3.58 & 0.76 & Moderate \\
\hline
\end{tabular}

Table 1: Mean Values and Standard Deviation for Each Construct on Role of Management in Empowering Lecturers in Tahfiz Institution

\section{Empowerment by Spiritual Faith Incentives}

To visualize the level of empowering lecturers by employer through spiritual faith incentives, the mean value and standard deviation were measured as shown in Table 2. 


\begin{tabular}{|c|c|c|c|c|c|}
\hline & Items & Mean & S.D & $\%$ Agreed & Level \\
\hline 1 & $\begin{array}{l}\text { Nourishing the principle that every job will be accountable before } \\
\text { Allah }\end{array}$ & 4.38 & 0.93 & $88.7 \%$ & High \\
\hline 2 & $\begin{array}{l}\text { Instilling awareness that teaching the Quran can make one closer } \\
\text { to Allah }\end{array}$ & 4.34 & 0.96 & $84,8 \%$ & High \\
\hline 3 & Instilling principle of sincerity in work & 4.31 & 1.00 & $87.0 \%$ & High \\
\hline 4 & Instilling awareness that work is an ibadah (worship) & 4.25 & 1.00 & $87.0 \%$ & High \\
\hline 5 & $\begin{array}{l}\text { Instilling awareness that perseverance in work leading to blessings } \\
\text { from Allah and rewards from Him }\end{array}$ & 4.25 & 0.99 & $85.3 \%$ & High \\
\hline 6 & $\begin{array}{l}\text { Lecturers are reminded that working is a mean of obeying Allah } \\
\text { command }\end{array}$ & 4.23 & 1.03 & $84.8 \%$ & High \\
\hline 7 & $\begin{array}{l}\text { Lecturers are reminded that knowledge and practice are roots in } \\
\text { the height of dignity in the sight of Allah }\end{array}$ & 4.23 & 1.00 & $81.9 \%$ & High \\
\hline 8 & $\begin{array}{l}\text { Lecturers are reminded that Allah the Almighty forbids laziness } \\
\text { and unemployment }\end{array}$ & 4.21 & 1.02 & $75.7 \%$ & High \\
\hline 9 & $\begin{array}{l}\text { Instilling the principle that Allah is monitoring (Allah is Most } \\
\text { Watchful) to every act and word }\end{array}$ & 4.21 & 1.04 & $75.2 \%$ & High \\
\hline 10 & $\begin{array}{l}\text { Nourishing an understanding that Allah puts responsibility upon } \\
\text { man to prosper the earth by doing good deeds }\end{array}$ & 4.16 & 1.03 & $75.4 \%$ & High \\
\hline 11 & $\begin{array}{l}\text { Instilling principle of trust in Allah after exerting effort for } \\
\text { excellent work }\end{array}$ & 4.12 & 1.04 & $81,4 \%$ & High \\
\hline 12 & $\begin{array}{l}\text { Encouraging lecturers to appreciate texts from the Quran and } \\
\text { Hadith which call for diligence work }\end{array}$ & 4.11 & 1.03 & $81.9 \%$ & High \\
\hline 13 & To create awareness that working is a way of prophets and apostles & 4.01 & 1.09 & $78.0 \%$ & High \\
\hline \multirow[t]{2}{*}{14} & $\begin{array}{l}\text { Instilling awareness that the Companions (of the Prophet (pbuh)) } \\
\text { work and put effort to earn for their living }\end{array}$ & 3.88 & 1.09 & $73.3 \%$ & High \\
\hline & Total of Spiritual Faith Incentives & 4.19 & 0.93 & & High \\
\hline
\end{tabular}

Table 2: Mean Values and Standard Deviation for Each Item of Spiritual Faith Incentive by the Highest Mean Value Sequences

Table 2 shows the survey feedback from lecturers to measure items level in spiritual faith incentives where the mean value is around 3.884.38 which is at a high level. The table above also shows that the 13th item, which is "Nourishing the principle that every job will be accountable before God" is the highest level of the whole item at $88.7 \%$ of which the respondents agreed with the statement in this item. On the contrary, the 11th items of "Instilling awareness that the Companions (of the Prophet (pbuh)) work and put effort to earn for their living" is the lowest item in this section with $73.3 \%$ of respondents agree with this statement.

The findings on semi-structured interviews also showed that five out of six employers interviewed have stated that the management has attempted to provide spiritual faith incentives to lecturers such as 10 minutes awareness programs per day, encourage lecturers to join halaqah Quran and Tafseer, invite external speakers to motivate lecturers on work, continuous motivation on lecturer as being idol for students as well as encouraging them to give commitment to their work. Nevertheless there is an employer stating that there is no need to provide spiritual faith incentives since assuming that the lecturers have sufficient religious knowledge.

Based on the overall findings of this study, it was found that lecturers of the view that there are incentives for all three types of incentives, i.e., spiritual faith incentives, scheme of service incentives and working environment incentives. Nevertheless there is a gap between scheme of service incentives and the other two; spiritual faith incentive and maknawi incentives. This 
contrasts with the views of Badr (1985) and Fadhlullah (1996) which states that incentives which is balanced and just are complementary to each other. Meanwhile spiritual faith incentive which obtained the highest mean score from the feedback questionnaires and interview analysis showed that employers place great emphasis on the spiritual elements for empowering lecturers. This is perhaps a motivating factor for part time lecturers or visiting lecturers to continue their service even though they perceive management of the institute pay less attention to work incentives. This is supported with the findings from a pilot study by Marzuqi (2013) which states $81.8 \%$ of lecturers are satisfied with their jobs, even though $72 \%$ of them state that the management pay less attention to work incentives. Requirements and approval to spiritual incentive is also confirmed by Al-Ibrahim (1988) as the core of incentives, while rejecting the view of a finding from the interviews which state irrelevance of spiritual faith incentives for lecturers since they have sufficient religious knowledge.

\section{Empowerment by Material Incentive (Scheme of Service)}

To observe the empowering level of lecturers by employer through spiritual faith incentives, then the mean values and standard deviation for each item of questionnaire was analyzed and the findings of interviews among employers were submitted. Table 3 shows the feedback from lecturers to measure the level of empowerment for items in material incentive (scheme of service) where the mean value is between 2.25 to 3.18 which is at a moderate level. The table above also shows that the 25th item, which is "The optional pension scheme or EPF to ensure lecturers future" is the topmost item, and at a moderate level with only $51.9 \%$ respondents agreed to this statement. In contrast, the 11th items which is "Hafazan incentive scheme for lecturers who maintain their hafazan (memorizing the Quran)" is the last item in this section and is at a very low levels where only $26 \%$ respondents agreed to this statement.
The findings from semi-structured interviews show that five out of six employers interviewed have stated that the management have attempted to provide material incentives (scheme of service) to lecturers in various form such as organizing a family day, award to outstanding lecturers, increment and bonuses for civil servants, award scholarships to those continuing their studies at a higher level, health insurance, opportunities for promotion, and housing loans facility. Meanwhile, an employer stated that the management was unable to provide sufficient scheme of service incentive for lecturers as directed by the austerity policies of the government. This affects the smooth running of activities and lecturers program which contributed to lack of permanent employment offer in maahad tahfiz.

The findings of this survey indicate that most statements related to scheme of service incentive is at a moderate level. This may be due to the number of permanent lecturers at DQ and MTQN is only $51 \%$, and various service incentives are only enjoyed by this groups which are obtain from the finding in interviewing the employers. While the parttime, contract or visiting lecturers only enjoyed a small portion of services incentive provided. Thus improvement on services incentive should not be ignored because it act as a catalyst for improving lecturers teaching quality as has been evidenced from studies by Winter, Petrosko, and Rodriguez (2007). Similarly, services incentive may encourage research work among lecturers (Ston, 2006).

\section{Empowerment by Working Environment Incentives}

To observe the empowering level of lecturers by employer through spiritual faith incentives, the mean value and standard deviation for each item of the questionnaire were analyzed and the findings of interviews among employers were submitted. 
GJAT | JUNE 2016 | VOL 6 ISSUE $1 \mid 18$

ISSN : 2232-0474 | E-ISSN : 2232-0482

www.gjat.my

\begin{tabular}{|c|c|c|c|c|c|}
\hline & Items & Mean & S.D & $\%$ Agreed & Level \\
\hline 1 & $\begin{array}{l}\text { The optional pension } \\
\text { scheme or EPF to ensure } \\
\text { lecturer future }\end{array}$ & 3.18 & 1.48 & $51.9 \%$ & Moderate \\
\hline 2 & $\begin{array}{l}\text { Appropriate income with } \\
\text { task and work }\end{array}$ & 2.94 & 1.34 & $49.7 \%$ & Moderate \\
\hline 3 & $\begin{array}{l}\text { Opportunity in following } \\
\text { educational courses such } \\
\text { as diploma of education or } \\
\text { teaching certificate }\end{array}$ & 2.94 & 1.33 & $48.5 \%$ & Moderate \\
\hline 4 & $\begin{array}{l}\text { Continuous training to } \\
\text { enhance skills needed by } \\
\text { lecturers }\end{array}$ & 2.94 & 1.39 & $48.5 \%$ & Moderate \\
\hline 5 & $\begin{array}{l}\text { Disciplinary action taken } \\
\text { if found guilty of violating } \\
\text { work discipline (rules) }\end{array}$ & 2.93 & 1.35 & $40.0 \%$ & Moderate \\
\hline 6 & $\begin{array}{l}\text { Quarters (housing facility) } \\
\text { or housing benefit for } \\
\text { lecturers }\end{array}$ & 2.88 & 1.40 & $50.1 \%$ & Moderate \\
\hline 7 & $\begin{array}{l}\text { Housing loans facility for } \\
\text { lecturers }\end{array}$ & 2.86 & 1.40 & $53.1 \%$ & Moderate \\
\hline 8 & $\begin{array}{l}\text { Financial incentives } \\
\text { such as bonus schemes } \\
\text { and remuneration as an } \\
\text { incentive for lecturer } \\
\text { with outstanding work } \\
\text { performance }\end{array}$ & 2.84 & 1.32 & $54.2 \%$ & Moderate \\
\hline 9 & $\begin{array}{l}\text { Opportunities for } \\
\text { promotion for lecturer } \\
\text { according to excellence in } \\
\text { work performance }\end{array}$ & 2.79 & 1.29 & $69.7 \%$ & Moderate \\
\hline 10 & $\begin{array}{l}\text { Study leave for lecturers } \\
\text { to improve their academic } \\
\text { level and skills }\end{array}$ & 2.77 & 1.44 & $48.6 \%$ & Moderate \\
\hline 11 & $\begin{array}{l}\text { Sufficient study reference } \\
\text { for lecturers who carry out } \\
\text { research }\end{array}$ & 2.77 & 1.36 & $52.0 \%$ & Moderate \\
\hline 12 & $\begin{array}{l}\text { Permission to work outside } \\
\text { office hours for additional } \\
\text { income }\end{array}$ & 2.76 & 1.34 & $54.1 \%$ & Moderate \\
\hline 13 & $\begin{array}{l}\text { Health care or health } \\
\text { insurance for lecturers and } \\
\text { their family members }\end{array}$ & 2.74 & 1.41 & $49.1 \%$ & Moderate \\
\hline 14 & $\begin{array}{l}\text { Salary increment for } \\
\text { lecturers based on } \\
\text { their achievement and } \\
\text { performance }\end{array}$ & 2.65 & 1.18 & $38.5 \%$ & Moderate \\
\hline 15 & $\begin{array}{l}\text { A fair financial incentives } \\
\text { system to lecturers who } \\
\text { perform tasks other than } \\
\text { their basic task }\end{array}$ & 2.59 & 1.34 & $37.8 \%$ & Moderate \\
\hline 16 & $\begin{array}{l}\text { Incentives payment to } \\
\text { lecturers who produce } \\
\text { academic research }\end{array}$ & 2.52 & 1.34 & $45.2 \%$ & Moderate \\
\hline 17 & $\begin{array}{l}\text { Hafazan incentive scheme } \\
\text { for lecturers who maintain } \\
\text { their hafazan (memorizing } \\
\text { the Quran) }\end{array}$ & 2.25 & 1.32 & $26.0 \%$ & Low \\
\hline \multicolumn{2}{|c|}{ Total of Scheme of Service Incentives } & 3.05 & 1.20 & & Moderate \\
\hline
\end{tabular}

Table 3: Mean Values and Standard Deviation for Each Item in Material Incentives

(Scheme of Service) By the Highest Mean Value Sequences 
Table 4 shows the feedback from lecturers to assess the level of empowerment of items in the working environment incentives in which the mean value is between 3.53 to 4.02 , i.e. overall is at a high level. The table above also shows that the first and second item, which is "Instilling responsible attitude toward work and assignments" and "Timetable of lectures to suit the needs of lecturers and students", which are both top item on the item list and are at high level with $70.1 \%$ of respondents agreed with the first statement and $74.6 \%$ respondents agreed with the second statement. On the contrary, the 20th items, which is "Letters of appreciation to the outstanding lecturer" is the last item in this section and is at moderate level where only $57 \%$ of respondents agreed with this statement. The findings from semi-structured interviews also show that four out of six employers interviewed have stated that the management has tried to provide incentives such as creating a working environment that establish better communication among lecturers, give space to express their views, preserve the reputation of maahad tahfiz, award certificate of appreciation to the outstanding lecturer, provide appropriate learning infrastructure and strengthen solidarity among the lecturers. On the contrary, two employers have stated that the management were unable to provide any incentives for a good working environment as there is no learning environment for tahfiz al-Quran (sharing complex), as well as a loose collaboration from lecturers. The findings from questionnaires show that overall, maknawi incentive (working environment) is at a high level. Opportunity for lecturers to make decisions together, concern over lecturers' complaints and recognition in the form of an appreciation letter are given less attention by employers. Furthermore findings from interviews show that less attention are given by management to maknawi incentives in the form of Teaching \& Learning environment that is conducive and in the spirit of cooperation between lecturers. Let not underestimated this because according to Kinuthia (2006), lecturers prefer non-material incentives than material incentives.

\section{Conclusion}

In general, the employers of tahfiz institutions in Malaysia have been trying to offer various incentives to lecturers. But the gap between scheme of service incentives and both spiritual faith incentives and maknawi incentives (working environment) need to be improved. Scheme of service incentives should be improved and enhanced, especially in providing incentive for lecturers in retaining hafazan for qualified lecturers. The management should also pay attention to improve some form of maknawi incentives (working environment) such as recognition of work, T\&L environment which is conducive and strengthening the relationship and cooperation among lecturers. All kinds of encouragements and incentives are ultimately intended to achieve the pleasure of Allah as well as empowering lecturers to improve their performance which in turn leads to the institutions excellence. 
GJAT | JUNE 2016 | VOL 6 ISSUE 1 | 20

ISSN : 2232-0474 | E-ISSN : 2232-0482

www.gjat.my

\begin{tabular}{|c|c|c|c|c|c|}
\hline & Items & Mean & S.D & $\%$ Agreed & Level \\
\hline 1 & $\begin{array}{l}\text { Instilling responsible } \\
\text { attitude toward work and } \\
\text { assignments }\end{array}$ & 4.02 & 1.04 & $70.1 \%$ & High \\
\hline 2 & $\begin{array}{c}\text { Timetable of lectures to suit } \\
\text { the needs of lecturers and } \\
\text { students }\end{array}$ & 4.02 & 0.97 & $74.6 \%$ & High \\
\hline 3 & $\begin{array}{l}\text { Providing adequate recess } \\
\text { period while on duty }\end{array}$ & 4.01 & 0.88 & $80.4 \%$ & High \\
\hline 4 & $\begin{array}{c}\text { Good communication } \\
\text { within and outside the } \\
\text { institute }\end{array}$ & 4.00 & 1.04 & $78.5 \%$ & High \\
\hline 5 & $\begin{array}{l}\text { To promote good relations } \\
\text { between lecturers and } \\
\text { administration }\end{array}$ & 3.92 & 1.13 & $76.8 \%$ & High \\
\hline 6 & $\begin{array}{l}\text { Instilling a sense of pride } \\
\text { and affection to institutions } \\
\text { through duties as a lecturer }\end{array}$ & 3.92 & 1.07 & $65.6 \%$ & High \\
\hline 7 & $\begin{array}{l}\text { Giving freedom by instilling } \\
\text { self-regulation based on the } \\
\text { institution work ethics }\end{array}$ & 3.91 & 0.97 & $76.3 \%$ & High \\
\hline 8 & $\begin{array}{l}\text { Freedom to present their } \\
\text { academic views within } \\
\text { lecturer duties framework }\end{array}$ & 3.89 & 1.09 & $61.0 \%$ & High \\
\hline 9 & $\begin{array}{c}\text { Encouragement for lecturers } \\
\text { to accomplish task in } \\
\text { teamwork }\end{array}$ & 3.88 & 1.11 & $59.3 \%$ & High \\
\hline 10 & $\begin{array}{l}\text { Build confidence among } \\
\text { lecturers }\end{array}$ & 3.87 & 1.08 & $73.5 \%$ & High \\
\hline 11 & $\begin{array}{l}\text { Information and clear } \\
\text { instructions to facilitate the } \\
\text { duties of lecturers }\end{array}$ & 3.85 & 1.07 & $70.6 \%$ & High \\
\hline 12 & $\begin{array}{l}\text { Consider all the } \\
\text { circumstances before any } \\
\text { disciplinary action is taken }\end{array}$ & 3.85 & 1.05 & $70.1 \%$ & High \\
\hline 13 & $\begin{array}{l}\text { To be fair and not biased } \\
\text { toward any lecturers }\end{array}$ & 3.79 & 1.19 & $78.0 \%$ & High \\
\hline 14 & $\begin{array}{c}\text { Opportunity to participate } \\
\text { in academic seminars or } \\
\text { competitions at home and } \\
\text { abroad }\end{array}$ & 3.79 & 1.06 & $80.2 \%$ & High \\
\hline 15 & $\begin{array}{l}\text { Awards and compliments } \\
\text { from administrators to } \\
\text { successful of lecturer }\end{array}$ & 3.70 & 1.08 & $65.6 \%$ & High \\
\hline 16 & $\begin{array}{l}\text { Encouragement for lecturer } \\
\text { to carry out academic } \\
\text { research }\end{array}$ & 3.70 & 1.07 & $67.2 \%$ & High \\
\hline 17 & $\begin{array}{l}\text { Instilling confidence that } \\
\text { working in the institution is } \\
\text { assured }\end{array}$ & 3.67 & 1.10 & $61.0 \%$ & High \\
\hline 18 & $\begin{array}{l}\text { Opportunities to participate } \\
\text { in collective decision } \\
\text { making for the institution }\end{array}$ & 3.66 & 1.10 & $63.2 \%$ & Moderate \\
\hline 19 & $\begin{array}{l}\text { Serious attention is taken } \\
\text { on any suggestions and } \\
\text { complaints from lecturers }\end{array}$ & 3.64 & 1.20 & $66.1 \%$ & Moderate \\
\hline 20 & $\begin{array}{l}\text { Letters of appreciation to } \\
\text { the outstanding lecturer }\end{array}$ & 3.54 & 1.19 & $57.0 \%$ & Moderate \\
\hline \multicolumn{2}{|c|}{ Total of Working Environment Incentives } & 3.83 & 0.90 & & High \\
\hline
\end{tabular}

Table 4: The Mean Values and Standard Deviation for Each Item of Maknawi Incentives (Working Environment) By the Highest Mean Value Sequences 


\section{References}

Al-Quran.

Abu Zeinah, F., Al-Shyiyab, A. H., Ubabneh, I., \& Al-Naiemi, M. (2006). El-Ihso fil bahs el-ilmi. Amman: Dar El Maserah Linnasyar.

Al-Bukhari, M. B. (2011). Sohih al-Bukhari. Giza, Mesir: Alfa Linnasyar wa al-tauzi’.

Al-Ibrahim, Muhammad Uqlah. (1988). Hawafizul amal baina Islam wa al-Nazariyyat al-Wadiyyah. Amman. Maktabah Risalah AlHadisah.

Al-Ibrahim, Muhammad Uqlah. (2013). Model Insentif Kerja Islam. Temu bual, 24 Feb.

Al-Khatib, Ahmed. (2009). Al-Taalim al-Aliy: al-Isyakaliyat wa al-Tahadiyyat. Irbid: 'Alamul Kutub Al-Hadis.

Al-Rabiie, Said Hamad. (2008). Al-Taalim alAliy fi Asr al-Ma'rifah: al-Taghayyurat wa alTahadiyat wa Afaaq al-Mustaqbal. Amman: Dar al-syuruq.

Azmil Hashim. (2010). An Evaluation Of The Implementation of Tahfiz Curriculum in Darul Quran JAKIM and States Institutes Of Tahfiz Al-Quran. Unpublished Ph.D Thesis, University Kebangsaan Malaysia.

Azmil Hashim, Ab Halim Tamuri, \& Misnan Jemali. (2013). Latar Belakang Guru Tahfiz Dan Amalan Kaedah Pengajaran Tahfiz AlQuran Di Malaysia. Online Journal of Islamic Education, 1(1).

Badar, Hamad Ahmad. (1985). Daur Al-Deen Al-Islami Fi Nizom Dawafi Wa Hawafizul Amal Lada A'dha' Haiati Tadris Bijamiatai Daulatai Al-Kuwait Wal Urdun. Majallat AlUlum Al-Ijtimaiyyah, 13 (4), 291-328.

Darul Quran, (2013). Senarai Nama Penulis Jurnal Darul Quran. Unit Penerbitan Darul
Quran.

Fadhlullah, Ali Fahdlullah. (1996). Al-Ujur wal Hawafiz fi al-Islam: Qadaya Manhajiyyah. AlMajallat Al-Arabiyyah Liddirasat Al-Amniyyah wa Al-Tadrib (22), 45-71.

Fatahurrahman M.H. (2005). Tahap Kualiti Hafazan Al-Quran Dan Faktor-Faktor Yang Mempengaruhinya. Satu Kajian Ke Atas Pelajar Semester Enam Darul Quran. Projek Penyelidikan Darul Quran.

Kinuthia, W. (2006). Exploring Faculty Incentives and Barriers to Participation in Web-Based Instruction. International Journal of Education Reform, 15 (2), 289-300.

Mohamad Marzuqi A. R. (2008). Pengajaran Mata Pelajaran Hafazan Al-Quran: Suatu Kajian Maahad Tahfiz Al-Quran Zon Tengah. Laporan Projek Sarjana, Fakulti Sains Kognitif dan Pembangunan Manusia: Universiti Pendidikan Sultan Idris.

Mohamad Marzuqi A. R. (2013). Kajian Rintis Kepuasan Pensyarah Terhadap Insentif Kerja di Institusi Tahfiz Malaysia.

Ston, C. (2006). Incentives Stimulate Faculty Leardership in Research. Human Ecology , 34 (1), 7-19

Winter, P., Petrosko, J., \& Rodriguez, G. (2007). Using Economic Incentives to Recruit College Faculty Effects of Strating Salary and Healthcare Benefits Plan, Community College. Journal of Research and Practice, 31 (1), 19-35.

Zawawi Ismail. (2008). Penilaian Pelaksanaan Kurikulum Kemahiran Bertutur Bahasa Arab Komunikasi Di Sekolah-Sekolah Menengah Kebangsaan Agama. Tesis Dr. Falsafah. Universiti Kebangsaan Malaysia, Bangi. 
